\title{
Burnout Syndrome: Determinants and Predictors among Medical Students of Tanta University, Egypt
}

\author{
Salwa A.Atlam ${ }^{1}$ \\ ${ }^{1}$ Public Health and Community Medicine, Faculty of Medicine, Tanta University, Egypt
}

Received: November $2016 \quad$ Accepted : March 2017

\begin{abstract}
Objective: to study the magnitude of burnout syndrome, its determinants and predictors among medical students of Tanta University.Methods:A cross-sectional study was conducted using The Copenhagen Burnout Inventory (CBI) and a structured sociodemographic questionnaire.Results:Burnout syndrome was diagnosed in $79.9 \%$ of the studied students. $56.8 \%$ and $60 \%$ of them suffered personal and work-related burnout respectively, whereas $38.2 \%$ and $28.9 \%$ suffered teacher and colleague burnout correspondingly.A significant association was found between all subscales of burnout and thoughts of quitting the course.Significant association was also evident between personal, work and colleagues related burnout and difficulties in achieving academic goals. The odds of having burnout were 2.4 significantly greater for thoughts of quitting the medicine study. It was 1.9 times significantly higher with difficulty to achieve academic goals and was1.7 higher among students at the clinical stage. Burnout was higher among students who were dissatisfied with studying medicine.Conclusion:Burnout and/or its subscales were quite obvious amongst Medical Students of Tanta University especiallyat the clinical level of study.Disappointment with coursework and difficulties in achieving academic goalslead somestudents totake medication because of studying or thinkquitting the program.
\end{abstract}

Keywords:Burnout syndrome; medical students; determinants; predictors

Corresponding author: Salwa A. Atlam, E-mail: salwaatlam@yahoo.com

\section{Introduction}

Burnout is a syndrome of emotional exhaustion, depersonalization and a sense of low personal accomplishment that leads to decreased effectiveness at work. ${ }^{1,2}$ Burnout is defined as a response, which may be inappropriate, to chronic emotional and interpersonal stressors in the workplace. The term may be applied to individuals who engage in activities that are psychologically similar to work, such as students. ${ }^{3,4} \quad$ Burnout Syndrome amongst students has three dimensions: 1)emotional exhaustion (due to educational demands), 2) cynicism (indifference/apathetic attitude toward academic activities), and 3) low professional value (awareness of ineffectiveness as a student). ${ }^{5}$

Medical students have beenworrying education surroundings that involve dealing with an overload of classes, patient diseases, and contradictory contact with staff members. ${ }^{6}$

Demanding moments in thescholastic years ofmedical studentsand medicaltraining are well thought-out to have high mind toxicity. Factors which furtherlyadded pressure uponstudents inmedical schools consist of adaptation difficulties atthe startof coursework due to competitive entrance exams, leaving high school for the interpersonal realities ofsuperior independence and 
tasks.Moreover, the disappointment caused by a basic sciences cycle that does not match the budding new physicians who want immediate handling of definite medical disciplines. ${ }^{6,7}$

The excessive workload and educational necessities, combined with, a lack of time for leisure, family and friends, the choice of a speciality and the delayed income contribute to stress among medical students ${ }^{7,8}$. Previous studies on Burnout Syndrome among medical students have reported prevalence from $10 \%$ to over $45 \%{ }^{9,10-14}$ According to Ragaa El-Masry et al 2013, the prevalence of emotional exhaustion and high levels of perceived stress was 76.8 and $71.7 \%$ respectively. ${ }^{15}$. Whereas Abdul-Rahman E. Albalawi et al 2017, reported that, The burnout was concluded in $48.6 \%$ among medical students in Tabuk University of Saudi Arabia. ${ }^{16}$

The burnout syndrome in medical students, has a negative impact on a personal level (increased risk of suicidal ideation, depression and anxiety, interpersonal difficulties), on a professional level (compromised patient care, increased medical errors, lower satisfaction with career, poor performance and poor quality of life), and onthe academic level (it is correlated with thoughts of quitting the course); hence the importance of studying this syndrome. ${ }^{9,10,17-22}$ This was the motivating factors to carry out the present study.

\section{Methods}

Study design and Setting: A crosssectional study was carriedout amongMedical students of Tanta University. ThroughSeptemberuntil October 2016. The studysample was taken from allacademic grades bymultiple clusters random sample technique from students of Tanta Faculty of Medicine. Using Epi-info program based on the $45 \%$ prevalence rate found in thepast literature, ${ }^{21}$ with a confidence level of $90 \%$, and $5 \%$ confidence limits, 536 is the minimal number of students could be included in the study. For better accuracy, validity and to cover any losses due to incomplete questionnaire 672 students were included in the study after exclusion of students who did not answer all of the questionnaire items.

Inclusion criteria: Medical students in all academic years in the faculty of Medicine Tanta-University. Exclusion criteria: Students of other faculties and those who refuse to participate in the study.

Study Tools: Alargenumber ofstudies onburnout hadengaged theMaslach Burnout Inventory (MBI $)^{24}$. In this study, another tool for the measurement of burnout was used: the Copenhagen Burnout Inventory (CBI). ${ }^{25}$ The CBI consists of three scales measuringpersonal burnout, work-related burnout, and client-related burnout, for use among university students works related burnout is related to academic activities and client-related burnout could be modified into colleagues related and teachers related burnout. CBI was found to havehigh validity and reliability, and non-response rates were small. The CBI had been used in a number of countries and translated into eight languagesnot including Arabic one. ${ }^{24,25}$ The questionnaire is formed of; part one: personal burnout with 6 questions, part two: Work-related burnout composed of 7questions, part three: colleagues-related burnout which is composed of 6 questions and part four: teachers-related burnout which is composed of 6 questions.Response categories were assessed on a five-point Likert scale: Always, Often, Sometimes, Seldom, Never/almost never. Scoringwas: Always: 100. Often: 75. Sometimes: 50. Seldom: 25. Never/almost never: 0. Total score on the scale is the average of the scores on the items. Average $\geq 50$ means positive burnout. Another part of the

No. 1

January 2018 
questionnaire was designed for the personal and socio-demographic data of the participants, to assess: age, gender, socio-economic status indicated by the number of rooms in the house, academic year, perceptions about the ease or difficulty of achieving the academic goals, satisfaction with the course, using medications because of study and thinking of quitting medical study. Also, questions for smoking and hobbies as special habits of students were added.

Statistical analysis of data: Data were analysed using SPSS (Statistical Package for Social Science, version 20, SPSS Software, SPSS Inc., Chicago, USA).In categorical data, aChi-squared test was used for comparison between groups. Factors predicting high levels of stress and burnout on univariate analysis were entered into the multivariate logistic regression analysis to find the independent predictors of burnout. Odds ratio and $95 \%$ confidence interval werecalculated. $\mathrm{P} \leq 0.05$ was considered statistically significant.

\section{Ethical consideration}

Approval oral consent obtained from students to participate in the study and those who refuse to participate were excluded. Subjects were informed about the purpose and procedure of the study and benefits of sharing in it. Confidentiality and privacy were guaranteed during the whole period of the study.Approval of Ethical Committee of The Scientific Research in Tanta Faculty of Medicine was obtained before starting the study.

\section{Results}

Table (1), displays characteristics of 672 medical students in this study, $61.2 \%$ of them aged $\leq 21$ years; two-thirds of them $(65.5 \%)$ were females. Also half of the studied students $(51.5 \%)$ were from urban areas. Two-thirds of the students $(65.3 \%)$ were in the clinical stage of the Medicine studying. The studied students were of moderate to high socioeconomic status as $66.1 \%$ reported that the number of their households was more than 2 rooms. More than half of the students $(50.3 \%)$ and $(43.0 \%)$ respectively reported that they never /rarely or sometimes took medications due to studying. $50.1 \%$ and $11.5 \%$ of the participants reported that they sometimes and frequently had thoughts of quitting the course respectively. Three-quarters $(76.8 \%)$ of the participants found that achieving academic goals was hard. Nearly half $(45.8 \%)$ of the students were not satisfied on studying Medicine. $66.2 \%$ of the students had hobbies and $97.3 \%$ didn't smoke.

Regarding frequencies of the burnout and its subscales among studied students, figure(1), shows that burnout was found among $79.9 \%$ of the studied students, in the form of $56.8 \%$ and $60 \%$ of the students suffered personal burnout and work-related burnout respectively. Whereas $38.2 \%$ and $28.9 \%$ suffered teacher and colleague burnout correspondingly. There was also a positive significant correlation between the different types of burnout as shown in table 2. with the strongest correlation found between personal burnout and work burnout $(\mathrm{r}=.361, \mathrm{P}=.000)$ and the weakest one was between personal burnout and colleagues burnout $(\mathrm{r}=.177$, $\mathrm{P}<0.001)$ Table (3) and (4) display that, $58.62 \%, 60.15 \%, 31.41 \%, 44.83 \%$ of the students aged $>21$ years of age suffered personal, work, colleague, and teacher related burnout respectively with a significant association between age of the students and teacher related burnout only ( $\mathrm{P}=0.005)$. There was a significant association between gender and personal burnout $(\mathrm{p}<0.001)$ with a female predominance $(63.86 \%)$ and teacher burnout $(\mathrm{p}<0.001)$ with more frequency among males $(47.84 \%)$.More than half $(58.28 \%)$ of students from rural areas 
suffered personal burnout with a significant association between residence and personal burnout only $(\mathrm{P}=0.048)$. More than two-thirds $(68.5 \%)$ and nearly three-quarters $(71.6 \%)$ of the clinical stage students suffered colleague and teacher burnout with a significant association occurred between academic level and both work-related $(\mathrm{P}=0.035)$ and teacher-related burnout ( $\mathrm{P}=0.007)$. $69.04 \%$ and $62.22 \%$ of students suffered work-related burnout reported that they sometimes and frequently in that order took medication due to studying with significant association between taking medication and only work related burnout $(\mathrm{P}=0.002)$ There was also a significant association between all types of burnout and thoughts about quitting the course; where $63.5 \%$ and $68.8 \%$ of students suffered personal burnout reported that they sometimes and frequently faced these thoughts respectively. Moreover, $66.17 \%$ and $73.73 \%$ of students suffered work-related burnout sometimes and frequently complained thoughts of quitting course in that order. Regarding teacherrelated burnout $30.6 \%$ and $37.7 \%$ reported sometimes and frequently faced thoughts of quitting the course correspondingly. Also sometimes and frequent thoughts of quitting course were found among $41.8 \%$ and $50.7 \%$ of students with colleagues relate burnout correspondingly. More than half $(59.7 \%)$ of the students suffered personal burnout, $63.37 \%$ of workrelated burnout students, and onethird $(31.01 \%)$ of colleagues related burnout students respectively reported that it was hard to achieve their academic goals with significant association occurred between personal, work-related and colleagues related burnout and achieving academic goals. Nearly twothirds $(64.3 \%)$ of students with personal burnout, nearly three quarters $(70.8 \%)$ of students with work-related burnout, more than one third of students $(36.7 \%)$ with colleagues related burnout and nearly half of students $(49.03 \%)$ with teacher related burnout reported that they were significantly not satisfied with studying medicine.

Concerning multivariate analysis of associated factors with burnout table (5), displays that the odds of having burnout were2.4 (CI=1.577-3.560) significantly greater for thoughts of quitting medicine studying. It was 1.9 (CI 1.219-2.904) times significantly higher with finding it is hard to achieve academic goals. It was $1.7 \quad(\mathrm{CI}=1.019-2.856)$ higher among those who were in the clinical stage of studying medicine. Odds of having burnout was found 0.6 ( $\mathrm{CI}=.72-.878)$ significantly higher among students who were not satisfied on studying medicine.

\section{Discussion}

Whilst students experience theeducation andthe learning course, they might pick out diverse situations linked to academic activities as worrying.Consequently, it is likely that they employ coping strategies toreduce the effects of stress. On the other hand,when thesestrategies are unsuccessful stress ruins and may lead the students toexperience burnout. ${ }^{(26)}$ In the current study burnout was found in $79.9 \%$ and the burnout subscales among the studied students, were $56.8 \%$ and $60 \%$ personal burnout and work-related burnout respectively. Whereas $38.2 \%$ and $28.9 \%$ suffered teacher and colleague burnout correspondingly. In another study done by Chin RWA.2016, in Malaysia using CBI on medical students $(67.9 \%)$ medical students experienced burnout. Personal burnout was the highest (81.6\%), followed by work-related burnout $(73.7 \%)$ and client-related burnout $(68.6 \%) .{ }^{27}$ The prevalence of burnout amongst medical students has been found to be comparatively high, between $45 \%$ and $71 \%$ of students affected in different studies. ${ }^{(22,28-30)}$ In the current study, work-related burnout(academic activities) higher than personal burnout 
this may be explained as burnout in those students is mainly due to the academic overburden more than the emotional exhaustion. Thus immediate intervention should be done by college administrator to relieve the load on students regarding academic activities.

In the present study, there was a significant association between age of the students and teacher related burnout. Also, More than two-thirds and nearly three-quarters of the clinical stage students suffered significantly colleague and teacher burnout. The age was found to be significantly associated with burnout in another study done by Dyrbye, et al.2006', which showed that senior medical years are associated with greater burnout. ${ }^{(19)}$ This also was in agreement with another study where the prevalence of client related burnout was highest among older students and clinical stage ones. ${ }^{27}$ In this context, clients were referred to the person to whom the respondents spent most of their time with during the academic session, for example, lecturers, and friends. The client-related burnout among senior medical students could be a result of having difficulties in adapting tolecturers' teaching style which was different from that of their pre-clinical stage. Moreover, there was possible insufficient educational support from their teachers or colleagues in view of the newly-implemented curriculum. Special intervention programs could be set to deal with the teacher-related burnout all the way through educational strategies. ${ }^{31}$ This was in agreement also withother studies that reported a deterioration in students' mental health as the course progresses ${ }^{6}$, and burnout increases as students enter more advanced periods. ${ }^{5,10}$ Other study showed no significant association between prevalence of burnout and particular year of the study. ${ }^{14}$ In the current study, There was a significant association between gender and personal burnout with a female predominance and teacher burnout with more frequency among males. This was in agreement with the study done in Malaysia 2016, by Chin RWA et al. where, a higher number of female medical students reported burnout $(68.10 \%)$ than male medical students $(67.7 \%){ }^{27}$ These findings are comparable with a study that found approximately $50 \%$ of female and $33 \%$ of male medical students experiencedpsychological stress. ${ }^{32}$ The female predominance of burnout may be because, women tend to feel emotionally exhausted, whereas, men feel more depersonalised. Regarding gender,studies developed in the general population present contradictory results. Some find that gender differences are not very pronounced, however,they show that women present agreater emotional exhaustion than men, and that men have higherlevels of depersonalization than women ${ }^{33-35}$. However, other authors found that levels of depersonalization are morepronounced in women. ${ }^{36}$ Consequently, the stressors of medical school appear to impact female students more severely and, as a consequence, cause more frequent burnout in them. ${ }^{37}$ And, finally, another study presented no gender differences. ${ }^{9}$ In the present study, $58.28 \%$ of students from rural areas suffered significantly from personal burnout. This was not the condition in another study done byOriolYuguero et al 2016 in Spain, they found thatEmotional exhaustion and depersonalization scores were both lower among physicians and nurses working in rural areas. ${ }^{38}$ In the current study, students live in rural areas but join their college in the city with more stress due to longer time is taken by transportation, less time allowed for studying and higher expectations from their parents so they are more liable for emotional exhaustion and personal burnout. In the current study, students suffered work-related burnout reported that they sometimes and frequently took 
medication due to studying with a significant association between taking medication and only work-related burnout. This was true in other study done by Juliana et al,2009, the graduate students of the Faculty of Dentistry of Araraquara(São Paulo State University, protégées). ${ }^{(25)}$ However, no one can predict that, whether the intake of studies-related medication is a consequence of the onset of Burnout Syndrome ordrug intake may lead to burnout. So this suggestion should be considered with concern in the further studies.In this study, the students suffered burnout and its all subscales reported that they significantly had thoughts of quitting studying medicine. This was in agreement with theresults obtained by Carlotto et al 2006. ${ }^{5}$ This may be explained by theconclusion made by Batista et al.2010, concerning their study on burnout in teachers, where the authors stated that, the intention to abandon work can be considered as atrial to deal with the emotional exhaustion, often as a resultant ofthe deficient in the equilibrium between the investment made and the rewards obtained. ${ }^{39}$

In the current study,Students reported that it was hard to achieve their academic goals with significant association occurred between personal, work-related and colleagues related burnout and achieving academic goals. This also occurred in another study done by Muzafar et al 2014, on Pakistani Medical Students. They reported that stressors often cited by the students were: a large amount of study with slight balance, high frequency of tests, fear of failure, sense of boundless competition, achieving lesser than hoped for, and elevated parental expectations. ${ }^{37}$

In the present study,students suffered all burnout subscales were significantly not satisfied with studying medicine. This was the same as found in another study done by Costa EF et al 2012, in Clinics (Sao Paulo), they found that Although
$75.6 \%$ of the students believed that they were acquiring the skills necessary to become good professionals, only $29.4 \%$ were satisfied with the teaching strategies used. and $66.6 \%$ were uncomfortable with course activities. ${ }^{14}$

In the present study, on doing logistic regression analysis, it was found that clinical stage of the study, thoughts of quitting study, difficulties on achieving academic goals and dissatisfaction of studying medicine were the predictors of burnout syndrome among the study participants. This was in agreement with other studies. ${ }^{14,40,41}$ Accordingly the three variables related to the education process (thoughts of quitting, hard to achieve academic goals and satisfaction on studying medicine) were significantly associated with Burnout Syndrome. This finding supports the professional nature of this disorder, which has previously been documented by health and welfare social institutions. ${ }^{40,41}$ And this also explains why work related subscale of burnout is higher than personal burnout subscale in the current study. Dissatisfaction with the course in the clinical stage and education strategies might be linked to the long-established medical teaching model, counting a high workload, late getting in touch with patients, and extreme stress on test performance, leading some students to believe falling out of the program. ${ }^{41,42}$ Thus the lack of support from the college has been powerfully associated with students' burnout. ${ }^{41}$

Longitudinal studies are requiredto set up, which variables demonstrate actual contributory relations. This was acrosssectional study,dependent on selfreported information from students. Reporting prejudice mayresult from the participants' perceptions of the questions or the passion for stating their emotions in a persuaded style, or at least because of inaccuracies of their responses. Adding together, the study was carried 
out at only one university, which may bound the overview of the outcome.

\section{Conclusion}

Elevated frequencies of burnout and its subscales were noticeable amongst medical students in the clinical period.Disappointment from coursework and achieving academic goalsmay be linked to the usual medical education form,counting ahigh workload, postponed patient contact, andunnecessary stress on exam performance.These may lead somestudents totake medication because of studying or thinkquitting the program. Results of this study can be used to spotlight on clinicalyears as a chance to provide an improved,less worried, shiftfrom pre-clinicaland clinicalacademic study.

\section{References}

1. Maslach C. Burned-out. Hum Behav 1976; 5:16-22.

2. Maslach C, Goldberg J. Prevention of burnout: new perspectives. Applied Prevent Psychol 1998; 7:63-74.

3. Prins JT, Hoekstra-Weebers JE, Gazendam-Donofrio SM, Dillingh GS, Bakker AB, Huisman M, et al. Burnout and engagement among resident doctors in the Netherlands: a national study. Med Educ. 2010;44(3):236- 47.

4. Schaufeli WB, Martinez IM, Pinto AM, Salanova M, Bakker AB. Burnout and engagement in university students A cross-national study. J Cross Cult Psychol. 2002;33(5):464-81.

5. Carlotto MS, Camara SG. Caracter1'sticaspsicome'tricas do MaslachBurnoutInventory Student Survey (MBI-SS) emestudantesuniversita riosbrasileiros. Psico USF. 2006;11(2):167-73.

6. Dyrbye LN, Thomas MR, Harper W, Massie FS Jr, Power DV, Eacker A, SzydloDW, Novotny PJ, Sloan JA, Shanafelt TD. The learning environment and medical student burnout: a multicentre study. Med Educ.2009; 43(3):274-282

7. Tarnowski M, Carlotto MS. Burnout Syndrome in students of psychology. TemasemPsicologia. 2007;15(2):173-80.

8. Aguiar SM, Vieira APGF, Vieira KMF, Nóbrega JO, Aguiar SM. Prevalenncia de sintomas de estresseemestudantes de medicina. J Bras Psiquiatr. 2009;58(1):34-8.

9. Dyrbye LN, Thomas MR, Massie FS, Power DV, Eacker A, Harper W, et al. Burnout and suicidal ideation among U.S. medical students. Ann Intern Med. 2008;149(5):334-41.

10. Dyrbye LN, Thomas MR, Huntington JL, Lawson KL, Novotny PJ, Sloan JA, et al. Personal life events and medical student burnout: a multicenter study. Acad Med. 2006;81(4):374-84.

11. Dyrbye LN, Massie FS, Jr., Eacker A, Harper W, Power D, Durning SJ, et al. Relationship between burnout and professional conduct and attitudes among US medical students. JAMA. 2010 ;304(11):1173-80.

12. Guthrie E, Black D, Bagalkote H, Shaw C, Campbell M, Creed F. Psychological stress and burnout in medical students: a five-year prospective longitudinal study. J R Soc Med. 1998;91(5):237-43.

13. Willcock SM, Daly MG, Tennant CC, Allard BJ. Burnout and psychiatricmorbidity in new medical graduates. Med J Aust. 2004;181(7):35760.

14. Oliva Costa EF, Santos AS, Abreu Santos AT, Melo EV, Andrade TM. Burnout Syndrome and associated factors among medical students: a crosssectional study. Clinics. 2012;67(6):573579.

15. RagaaElmasry, Seba M.C., Randah M.H, Ahmed M.A., Tarek S. Perceived stress and Burnout among Medical Students during the Clinical Period of Their Education.Ibnosina J.Med.BS.2013;5(4)179-188 
16. Abdulrahman E. A., Turki S. A., Ahmed S. A. , Yousef M.A., Salem K. A., Hyder O. M. The assessment of the burnout syndrome among medical students in Tabuk University, a crosssectional analytic study. Basic Research Journal of Medicine and Clinical Sciences 2017;Vol. 6(1): 14-19 Available online http//www.basicresearchjournals.org. ISSN 2315-6864

17. Dunn LB, Iglewicz A, Moutier C. A conceptual model of medicalstudent well-being: promoting resilience and preventing burnout. AcadPsychiatry,2008; 32: 44-53.

18. Dahlin M, Joneborg N, Runeson B. Performance-based self-esteemand burnout in a cross-sectional study of medical students. Med Teach,2007;29: 43-48.

19. Dyrbye LN, Thomas MR, Huschka MM, Lawson KL, Novotny PJ, et al. A multicenter study of burnout, depression, and quality of life in minority and nonminority US medical students. Mayo ClinProc,2006; 81:1435-1442.

20. Dyrbye LN, Thomas MR, Shanafelt TD. Medical student distress: causes, consequences, and proposed solutions. Mayo ClinProc.2005; 80:1613-1622.

21. Jennings ML. Medical student burnout: interdisciplinary exploration and analysis. J Med Humanit.2009; 30: 253-269.

22. Dyrbye LN, Thomas MR, Power DV, Durning S, Moutier C, et al. Burnout and Serious Thoughts of Dropping Out of Medical School: AMulti-Institutional Study. Academic Medicine.2010; 85: 94-102.

23. Dyrbye LN, Thomas MR, Huntington JL, Lawson KL, Novotny PJ, Sloan. JA, et al. Personal life events and medical student burnout: a multicenterstudy. Acad Med. 2006;81(4):374-84.

24. Tage S. Kristensen, Marianne B., Ebbe V., \& Karl B. The Copenhagen Burnout Inventory: A new tool for the assessment of burnout. Work \& Stress, July/ September 2005; 19(3): 192/207

25. Juliana Alvares, Duarte Bonini Campos, Mary Sandra Carlotto, JoãoMarôco. Copenhagen Burnout Inventory - Student Version: Adaptation and Transcultural Validation for Portugal and Brazil. Psicologia: Reflexão e Crítica.2013; 26 (1), 87-97.

26. Da Silva et al.: Hardy personality and burnout syndrome among nursing students in three Brazilian universitiesan analytic study. BMC Nursing 2014 13:9.

27. Chin RWA, Chua YY, Chu MN, Mahadi NF, Yusoff MSB, Wong MS, et al. Prevalence of burnout among UniversitiSains Malaysia medical students. Education in Medicine Journal. 2016;8(3):61-74.

http://dx.doi.org/10.5959/eimj.v8i3.454

28. Dyrbye LN, et al. Burnout and suicidal ideation among US medical students. Ann Intern Med 2008;149:334341. [http://dx.doi.org/10.7326/00034819-149-5- 200809020-00008] [PMID: 18765703]

29. Guthrie E, et al. Psychological stress and burnout in medical students: a fiveyear prospective longitudinal study. J R Soc Med 1998;91:237-243. [PMID: 9764076]

30. Dyrbye LN, et al. Race, ethnicity, and medical student well-being in the United States. Arch Intern Med. 2007;167(19):2103-9.

[http://dx.doi.org/10.1001/archinte.167.1 9.2103] [PMID: 17954805

31. De Oliva Costa EF, Santos SA, de Abreu Santos ATR, de Melo EV, de Andrade TM. Burnout Syndrome and associated factors among medical students: a cross-sectional study. Clinics. 2012;67(6):573-579.

doi:10.6061/clinics/2012(06)05.

32. Backovic DV, Zivojinovic JI, Maksimovic J, Maksimovic M. Gender differences in academic stress and burnout among medical students in final 
years of education. PsychiatriaDanubina. 2012;24(2):175-81.

33. Maslach C, Schaufeli WB, Leiter MP.Job burnout. Annu Rev Psychol.2001; 52: 397-422.

34. Maroco J, Tecedeiro M (2009) Inventário de Burnout de Maslachparaestudantesportugueses.

Psicologia, Saúde\&Doenças .2009;10: 227-235.

35. Purvanova RK, MurosJP Gender Differences in Burnout: A MetaAnalysis. Journal of Vocational Behavior.2010; 77: 168-185.

36. Houkes I, Winants YHWM, Twellaar M. Specific determinants of burnout among male and female general practitioners: A cross-lagged and burnout in across-sectional study of medical students. Med Teach panel analysis. Journal of Occupational \& Organizational Psychology.2008; 81: 29: 43-48. 249-276.

37. Muzafar Y, Khan HH, Ashraf H, et al. Burnout and its Associated Factors in Medical Students of Lahore, Pakistan. Muacevic A, Adler JR, eds. Curious. 2015;7(11):e390. doi:10.7759/cureus.390.
38. OriolYuguero, Josep Ramon Marsal, Montserrat Esquerda, Luis Vivanco\& Jorge Soler-González. Association between low empathy and high burnout among primary care physicians and nurses in Lleida, Spain, European Journal of General Practice.2016, DOI: 10.1080/13814788.2016.1233173

39. Batista JBV, Carlotto MS, Coutinho AS, Augusto LGS. Prevalência da síndrome de burnout e features sociodemographics e labourers em professors de colas municipal da Cidade de João Pessoa, PB. Rev Bras Epidemiol 2010; 13(3): 502-12.

40. Gil-Monte PR, Carlotto MS, Camara SG. Validation of the Brazilian version of the 'Spanish Burnout Inventory' in teachers. Rev SaudePublica. 2010;44(1):140-

7. [PubMed]

41. Roh MS, Jeon HJ, Kim H, Han SK, Hahm BJ. The prevalence and impact of depression among medical students: a nationwide cross-sectional study in South Korea. Acad Med. 2010;85(8):138490. [PubMed]

42. Tarnowski M, Charlotte MS. Burnout Syndrome in students of psychology. Temasem

Psicologia.2007;15(2):173-80. 
Table (1): Characteristics, thoughts, satisfaction toward medicine studying and special habits of the students

\begin{tabular}{|l|l|l|}
\hline Characteristics & No & $\%$ \\
\hline Age groups & & \\
$\leq 21$ & 411 & 61.2 \\
$>21$ & 261 & 38.8 \\
\hline Gender & & \\
Males & 232 & 34.5 \\
Females & 440 & 65.5 \\
\hline Residence & & \\
Rural & 326 & 48.5 \\
Urban & 346 & 51.5 \\
\hline Academic level & & \\
Pre-clinical & 233 & 34.7 \\
Clinical & 439 & 65.3 \\
\hline Number of rooms in the house & & \\
$\leq 2$ rooms & 228 & 33.9 \\
\hline 2 rooms & 444 & 66.1 \\
\hline Medication intake due to studies & & \\
Never/rarely & 338 & 50.3 \\
Sometimes & 289 & 43.0 \\
Frequently & 45 & 6.7 \\
\hline Thoughts about quitting the course & & \\
Never & 258 & 38.4 \\
Sometimes & 337 & 50.1 \\
Frequently & 77 & 11.5 \\
\hline Achieving academic goals & & \\
Easy & 156 & 23.2 \\
Hard & 516 & 76.8 \\
\hline Satisfaction on studying Medicine & & 54.2 \\
Yes & 364 & 45.8 \\
No & 308 & 66.2 \\
\hline Hobbies & & 33.8 \\
Yes & 445 & 2.7 \\
No & 227 & 97.3 \\
\hline Smoking & 18 & \\
Yes & 654 & \\
No & & \\
\hline
\end{tabular}


Table (2): Correlations between different types of burnout

\begin{tabular}{|l|c|c|c|}
\hline & $\begin{array}{c}\text { Work burnout } \\
\mathbf{r}(\mathbf{P})\end{array}$ & $\begin{array}{c}\text { Teacher burnout } \\
\mathbf{r}(\mathbf{P})\end{array}$ & $\begin{array}{c}\text { Colleagues burnout } \\
\mathbf{r}(\mathbf{P})\end{array}$ \\
\hline Personal burnout & $0.361(<0.001)^{* *}$ & $0.160(<0.001)^{* *}$ & $0.177(<0.001)^{* *}$ \\
\hline Work burnout & & $0.280(<0.001)^{* *}$ & $0.226(<0.001)^{* *}$ \\
\hline Teacher burnout & & & $0.310(<0.001)^{* *}$ \\
\hline
\end{tabular}

**. Correlation is significant at the 0.01 level (2-tailed).

Table(3):Distribution of personal and work related burnout subscales according to socio-demographic characteristics, thoughts, satisfaction toward medicine studying and special habits of the students

\begin{tabular}{|c|c|c|c|c|}
\hline Characteristics & $\begin{array}{c}\text { Personal } \\
\text { burnout } \\
\text { No }(\%) \\
382(56.8)\end{array}$ & $\begin{array}{l}\mathrm{X}^{2} \\
(\mathbf{P})\end{array}$ & $\begin{array}{c}\text { Work } \\
\text { burnout } \\
\text { No }(\%) \\
403(60.0)\end{array}$ & $\begin{array}{l}\mathrm{X}^{2} \\
(\mathbf{P})\end{array}$ \\
\hline $\begin{array}{l}\text { Age groups } \\
\leq 21 \text { years } \\
>21 \text { years }\end{array}$ & $\begin{array}{l}229(55.72) \\
153(58.62) \\
\end{array}$ & $\begin{array}{l}0.548 \\
(.459) \\
\end{array}$ & $\begin{array}{l}246(59.85) \\
157(60.15) \\
\end{array}$ & $\begin{array}{l}.006 \\
(.938) \\
\end{array}$ \\
\hline $\begin{array}{l}\text { Gender } \\
\text { males } \\
\text { females }\end{array}$ & $\begin{array}{l}101(43.53) \\
281(63.86)\end{array}$ & $\begin{array}{l}25.591 \\
(.000)^{*}\end{array}$ & $\begin{array}{l}141(60.78) \\
262(59.55)\end{array}$ & $\begin{array}{l}0.096 \\
(.757)\end{array}$ \\
\hline $\begin{array}{l}\text { Residence } \\
\text { rural } \\
\text { urban }\end{array}$ & $\begin{array}{l}198(58.28) \\
184(53.18)\end{array}$ & $\begin{array}{l}3.908 \\
(.048)^{*}\end{array}$ & $\begin{array}{l}196(60.12) \\
207(59.83)\end{array}$ & $\begin{array}{l}.006 \\
(.938)\end{array}$ \\
\hline $\begin{array}{l}\text { Academic level } \\
\text { Pre-clinical } \\
\text { Clinical } \\
\end{array}$ & $\begin{array}{l}127(54.5) \\
255(58.1)\end{array}$ & $\begin{array}{l}0.795 \\
(.373)\end{array}$ & $\begin{array}{l}127(54.5) \\
276(68.5) \\
\end{array}$ & $\begin{array}{l}4.435 \\
(.035)^{*}\end{array}$ \\
\hline $\begin{array}{l}\text { Number of elements in the households } \\
\leq 2 \text { rooms } \\
>2 \text { rooms }\end{array}$ & $\begin{array}{l}130(57.02) \\
252(56.76)\end{array}$ & $\begin{array}{l}.004 \\
(.948)\end{array}$ & $\begin{array}{l}146(64.04) \\
257(57.88)\end{array}$ & $\begin{array}{l}2.375 \\
(.123)\end{array}$ \\
\hline $\begin{array}{l}\text { Medication intake due tostudies } \\
\text { Never/rarely } \\
\text { Sometimes } \\
\text { Frequently }\end{array}$ & $\begin{array}{l}183(54.14) \\
170(60.50) \\
29(64.44)\end{array}$ & $\begin{array}{l}2.527 \\
(.283)\end{array}$ & $\begin{array}{l}181(53.55) \\
194(69.04) \\
28(62.22)\end{array}$ & $\begin{array}{l}12.066 \\
(.002)^{*}\end{array}$ \\
\hline $\begin{array}{l}\text { Thoughts about quitting thecourse } \\
\text { Never } \\
\text { Sometimes } \\
\text { Frequently }\end{array}$ & $\begin{array}{l}115(44.57) \\
214(63.50) \\
53(68.83)\end{array}$ & $\begin{array}{l}26.434 \\
(.000)^{*}\end{array}$ & $\begin{array}{l}124(48.06) \\
223(66.17) \\
56(73.73)\end{array}$ & $\begin{array}{l}25.860 \\
\left(0.000^{*}\right)\end{array}$ \\
\hline $\begin{array}{l}\text { Achieving academic goals } \\
\text { Easy } \\
\text { Hard }\end{array}$ & $\begin{array}{l}74(47.44) \\
308(59.69)\end{array}$ & $\begin{array}{l}7.332 \\
(.007)^{*}\end{array}$ & $\begin{array}{l}76(48.72) \\
327(63.37)\end{array}$ & $\begin{array}{l}10.715 \\
(.001)^{*}\end{array}$ \\
\hline $\begin{array}{l}\text { Satisfaction on studying Medicine } \\
\text { No } \\
\text { Yes }\end{array}$ & $\begin{array}{l}198(64.29) \\
184(50.55)\end{array}$ & $\begin{array}{l}12.832 \\
(.000)^{*}\end{array}$ & $\begin{array}{l}218(70.78) \\
185(50.82)\end{array}$ & $\begin{array}{l}27.674 \\
(0.000)^{*}\end{array}$ \\
\hline $\begin{array}{l}\text { Hobbies } \\
\text { yes } \\
\text { no }\end{array}$ & $\begin{array}{l}257(57.75) \\
125(55.07) \\
\end{array}$ & $\begin{array}{l}.442 \\
(.506) \\
\end{array}$ & $\begin{array}{l}267(60.0) 1 \\
36(59.9)\end{array}$ & $\begin{array}{l}.000 \\
(.982)\end{array}$ \\
\hline $\begin{array}{l}\text { Smoking } \\
\text { yes } \\
\text { no }\end{array}$ & $\begin{array}{l}10(55.56) \\
372(97.4)\end{array}$ & $\begin{array}{l}.014 \\
(.905)\end{array}$ & $\begin{array}{l}13(72.22) \\
389(61.45)\end{array}$ & $\begin{array}{l}1.167 \\
(.280)\end{array}$ \\
\hline
\end{tabular}

*significant 
Table (4):Distribution of colleague and teacher related burnout subscales according to sociodemographic characteristics, thoughts, satisfaction toward medicine studying and special habits of the students

\begin{tabular}{|c|c|c|c|c|}
\hline Characteristics & $\begin{array}{c}\text { Colleague } \\
\text { burnout } \\
\mathrm{N}(\%) \\
194(28.9) \\
\end{array}$ & $\begin{array}{l}\mathbf{X}^{2} \\
(\mathbf{P})\end{array}$ & $\begin{array}{c}\text { Teacher } \\
\text { burn out } \\
N(\%) \\
257(38.2) \\
\end{array}$ & $\begin{array}{l}\mathbf{X}^{2} \\
(\mathbf{P})\end{array}$ \\
\hline $\begin{array}{l}\text { Age groups } \\
\leq 21 \text { years } \\
>21 \text { years }\end{array}$ & $\begin{array}{r}112(27.25) \\
82(31.41)\end{array}$ & $\begin{array}{l}1.350 \\
(0.245)\end{array}$ & $\begin{array}{l}140(34.06) \\
117(44.83)\end{array}$ & $\begin{array}{c}7.831 \\
(0.005)^{*}\end{array}$ \\
\hline $\begin{array}{l}\text { Gender } \\
\text { males } \\
\text { females }\end{array}$ & $\begin{array}{r}70(30.17) \\
124(28.18)\end{array}$ & $\begin{array}{l}.293 \\
(0.588)\end{array}$ & $\begin{array}{l}111(47.84) \\
146(33.18)\end{array}$ & $\begin{array}{c}13.82 \\
8(<0.001)^{*}\end{array}$ \\
\hline $\begin{array}{l}\text { Residence } \\
\text { rural } \\
\text { urban }\end{array}$ & $\begin{array}{l}102(31.29) \\
92(26.59)\end{array}$ & $\begin{array}{c}1.805 \\
(0.179)\end{array}$ & $\begin{array}{l}119(36.50) \\
138(39.88)\end{array}$ & $\begin{array}{c}0.813 \\
(0.367)\end{array}$ \\
\hline $\begin{array}{l}\text { Academic level } \\
\text { Pre-clinical } \\
\text { Clinical }\end{array}$ & $\begin{array}{r}67(28.8) \\
127(28.9)\end{array}$ & $\begin{array}{c}.002 \\
(0.962)\end{array}$ & $\begin{array}{l}73(31.33) \\
184(71.6)\end{array}$ & $\begin{array}{c}7.218 \\
(0.007)^{*}\end{array}$ \\
\hline $\begin{array}{l}\text { Number of rooms in the house } \\
\leq 2 \text { rooms } \\
>2 \text { rooms }\end{array}$ & $\begin{array}{r}66(28.95) \\
128(28.83)\end{array}$ & $\begin{array}{c}0.001 \\
(0.974)\end{array}$ & $\begin{array}{r}91(39.91) \\
166(37.39)\end{array}$ & $\begin{array}{c}0.407 \\
(0.524)\end{array}$ \\
\hline $\begin{array}{l}\text { Medication intake due to studies } \\
\text { Never/rarely } \\
\text { Sometimes } \\
\text { Frequently }\end{array}$ & $\begin{array}{l}87(25.74) \\
93(33.10) \\
14(31.11)\end{array}$ & $\begin{array}{c}3.265 \\
(0.195)\end{array}$ & $\begin{array}{r}130(38.46) \\
112(39.86) \\
15(33.33)\end{array}$ & $\begin{array}{c}0.498 \\
(0.780)\end{array}$ \\
\hline $\begin{array}{l}\text { Thoughts about quitting the course } \\
\text { Never } \\
\text { Sometimes } \\
\text { Frequently }\end{array}$ & $\begin{array}{r}62(24.03) \\
103(30.56) \\
29(37.66)\end{array}$ & $\begin{array}{c}6.312 \\
(0.043)^{*}\end{array}$ & $\begin{array}{r}77(29.84) \\
141(41.84) \\
39(50.65)\end{array}$ & $\begin{array}{c}14.568 \\
(0.001)^{*}\end{array}$ \\
\hline $\begin{array}{l}\text { Achieving academic goals } \\
\text { Easy } \\
\text { Hard }\end{array}$ & $\begin{array}{r}34(21.79) \\
160(31.01) \\
\end{array}$ & $\begin{array}{c}4.951 \\
(0.026)^{*}\end{array}$ & $\begin{array}{r}51(32.69) \\
206(39.92) \\
\end{array}$ & $\begin{array}{c}2.651 \\
(0.103) \\
\end{array}$ \\
\hline $\begin{array}{l}\text { Satisfaction on studying Medicine } \\
\text { No } \\
\text { Yes }\end{array}$ & $\begin{array}{r}113(36.69) \\
81(22.25)\end{array}$ & $\begin{array}{l}16.930 \\
(0.00)^{*}\end{array}$ & $\begin{array}{l}151(49.03) \\
106(29.12)\end{array}$ & $\begin{array}{c}27.988 \\
(<0.001)^{*}\end{array}$ \\
\hline $\begin{array}{l}\text { Hobbies } \\
\text { yes } \\
\text { no }\end{array}$ & $\begin{array}{r}123(27.64) \\
71(31.28)\end{array}$ & $\begin{array}{r}0.968 \\
(0.325)\end{array}$ & $\begin{array}{r}162(36.40) \\
95(41.85)\end{array}$ & $\begin{array}{c}1.887 \\
(0.169)\end{array}$ \\
\hline $\begin{array}{l}\text { Smoking } \\
\text { yes } \\
\text { no }\end{array}$ & $\begin{array}{r}5(27.78) \\
189(29.86)\end{array}$ & $\begin{array}{c}0.012 \\
(0.914)\end{array}$ & $\begin{array}{r}10(3.9) \\
247(96.1) \\
\end{array}$ & $\begin{array}{c}2.330 \\
(0.127) \\
\end{array}$ \\
\hline
\end{tabular}

*significant 
Table(5): Regression Analysis of Factors Associated with (Predictors) Burnout

\begin{tabular}{|l|r|r|r|r|r|r|}
\hline \multicolumn{1}{|c|}{ Predictors } & \multirow{2}{*}{ B } & Wald & \multirow{2}{*}{ Sig. } & \multirow{2}{*}{$\operatorname{Exp(B)}$} & \multicolumn{2}{c|}{$\begin{array}{c}\text { 95\% C.I. for } \\
\text { Exp(B) }\end{array}$} \\
\cline { 5 - 7 } & & & & & Lower & Upper \\
\hline Age groups(> 21years) & -0.337 & 1.615 & 0.204 & 0.714 & 0.425 & 1.200 \\
\hline Gender(females) & 0.133 & 0.400 & 0.527 & 1.143 & 0.756 & 1.728 \\
\hline Residence(rural) & -.0317 & 2.413 & 0.120 & 0.728 & 0.488 & 1.086 \\
\hline Academic level(clinical) & 0.534 & 4.135 & $0.042^{*}$ & 1.706 & 1.019 & 2.856 \\
\hline Med intake & -0.334 & 2.613 & 0.106 & 0.716 & 0.478 & 1.073 \\
\hline Thoughts of quitting study & 0.863 & 17.243 & $<0.001^{*}$ & 2.369 & 1.577 & 3.560 \\
\hline $\begin{array}{l}\text { Achieving academic goal } \\
\text { (hard) }\end{array}$ & 0.632 & 8.151 & $0.004^{*}$ & 1.882 & 1.219 & 2.904 \\
\hline $\begin{array}{l}\text { Satisfaction on studying } \\
\text { medicine (no) }\end{array}$ & -0.560 & 6.526 & $0.011^{*}$ & 0.571 & 0.372 & 0.878 \\
\hline Constant & 0.847 & 5.312 & 0.021 & 2.333 & & \\
\hline
\end{tabular}

Variable(s) entered on step 1: age groups, gender, residence, Academic level, medication intake due to studying, thoughts of quitting, numberof elementsinthehouseholds, achieving academic goal, satisfaction on studying medicine, hobbies, smoking.

* Significant

\section{Frequency of Burnout and Its Subscales}

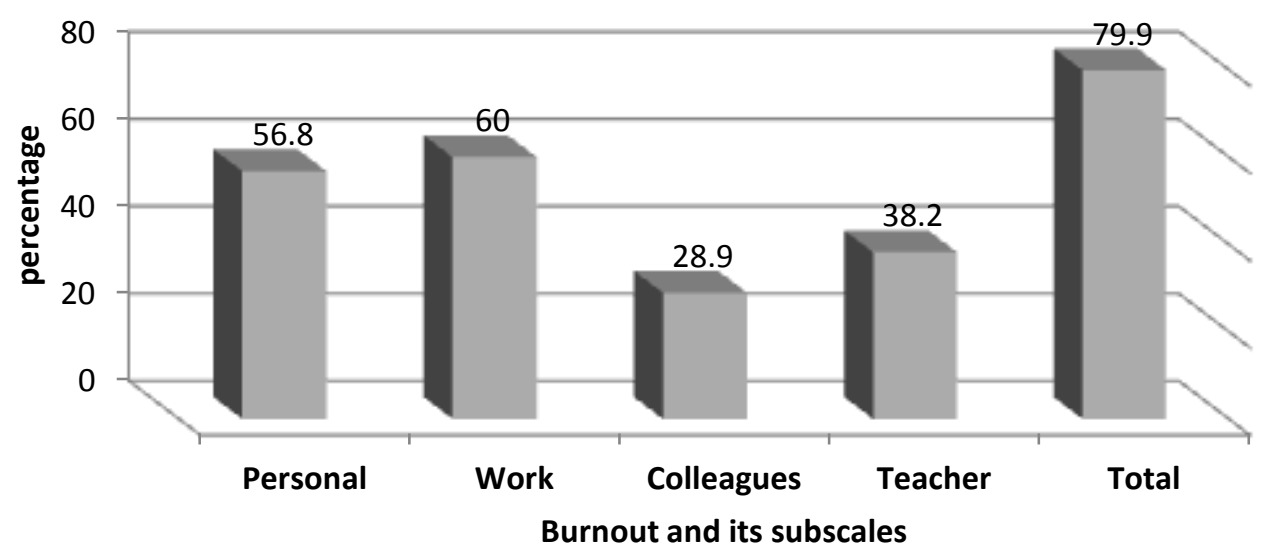

Fig.(1):Frequencies of the Burnout and ItsSubscalesAmong MedicalStudents 